KREATIF

Jurnal Ilmiah

Prodi Manajemen Universitas Pamulang
ISSN: 2339-0689 (Print), ISSN 2406-8616 (Online)

Volume 7, No 1 Juni 2019, (Halaman 1-17)

Tersedia online di http://openjournal.unpam.ac.id/index.php/kreatif

\title{
APLIKASI FUNGSI MANAGEMEN DALAM PENGELOLAAN SAMPAH TERPADU STT-PLN
}

\author{
Emillia, ${ }^{1 *}$ Hendrianto Husada, ${ }^{2}$ \\ ${ }^{1 a}$ Program Studi Teknik Mesin, STT-PLN \\ ${ }^{2 b}$ Program Studi Teknik Elektro, STT-PLN \\ emillia@sttpln.ac.id; hendrianto.husada@sttpln.ac.id
}

\begin{abstract}
ABSTRAK
Penelitian ini dilakukan dengan menggunakan metode eksplanatoris yang dilengkapi dengan penelitian di lapangan, yaitu di tempat olah sampah (TOS) yang berada di lingkungan kompleks STT-PLN Jakarta. Observasi lapangan tersebut juga disertai dengan metode question and aswer memberikan berbagai pertanyaan kepada sebagian besar peserta didik dan karyawan yang bekerja di tempat olah sampah (TOS) tersebut, ditambah dengan mempelajari berbagai materi acuan lainnya.

Tulisan ini merupakan hasil penelitian lanjutan terdahulu yang berjudul : "Metode Yuridis Pengelolaan Sampah Rumah Tangga Dan Sampah Sejenis Di STTPLN" yang membahas aspek hukum dalam pengelolaan sampah yang dilakukan oleh STT-PLN. Sedangkan dalam tulisan ini membahas tentang managemen pengelolaan sampah apabila ditinjau dari ilmu managemen. Permasalahan dalam tulisan ini adalah apakah pengelolaan sampah di STT-PLN sudah menggunakan prinsip managemen yang baik.

Berdasarkan hasil penelitian menunjukan bahwa STT-PLN sudah melaksanakan pengelolaan sampah terpadu yang baik dengan menggunakan fungsi-fungsi yang berlaku dalam dasar-dasar managemen yang baik dengan menggunakan prinsip 3R, yaitu reduce, reuse dan recycle.
\end{abstract}

Kata-kata kunci: sampah; pengelolaan; managemen; STT-PLN.

\section{ABSTRACT}

This research was carried out using explanatory methods which were supplemented by research in the field, namely in the trash can (TOS) located in the STT-PLN Jakarta area. The field observation was also accompanied by a method of giving various questions to the majority of students and employees who worked in the trash can (TOS), coupled with studying various other reference materials.

This paper is the result of a previous follow up study entitled: "Juridical Method of Household Waste Management and Similar Waste in STT-PLN" which discusses the legal aspects of waste management carried out by STT-PLN. Whereas in this paper discuss about management of waste management when viewed from management science. The problem in this paper is whether waste management in STT-PLN has used good management principles.

Based on the results of the study show that STT-PLN has implemented a good integrated management using the functions that aplly in the basics of good management using the $3 R$ principle, namely reduce, reuse and recycle.

Keywords: garbage, waste management, management science, STT-PLN 


\section{PENDAHULUAN}

Indonesia termasuk negara berpenduduk cukup besar yang setiap tahunnya selalu bertambah. Menurut data dari Biro Pusat Statistik dalam tenggang waktu 30 tahun belakangan ini jumlah penduduk meningkat sebesar dua kali lipat, yaitu tahun 1980 sebesar 147,49 juta orang dan pada tahun 1990 sebesar 179,37 juta orang kemudian pada tahun 2000 menjadi sebesar 206,26 juta orang. Selanjutnya ditahun 2005 pertambahan jumlah penduduk Indonesia mencapai sebesar 218,86 juta orang kemudian ditahun 2011 berjumlah sebesar 259.940.857 jiwa. Pertambahan jumlah penduduk yang demikian pesat tersebut memiliki dampak bagi besarnya jumlah sampah yang berasal dari aktivitas penduduk tiap tahunnya (Emillia, 2018).

Bertambahnya jumlah penduduk tersebut memiliki dampak bagi menurunnya kemampuan sumber air, tanah dan udara dalam menyerap berbagai buangan yang berasal dari aktivitas penduduk sehari-hari. Oleh karena itu peningkatan jumlah penduduk secara tidak langsung berdampak semakin besarnya jumlah sampah diperkotaan (Emillia, 2018).

Peningkatan jumlah penduduk juga berakibat bagi penghasilan perkapita. Sehingga Biro Pusat Statistik menetapkan standar kehidupan keluarga yang tidak mampu adalah penghasilan yang sama sekali tidak dapat memenuhi seluruh kebutuhan hidup keluarga sehari-hari, yaitu dapat dilihat bahwa pada bulan Maret 2011 standarnya adalah kebutuhan rumah tangga sehari-hari sebesar Rp. 233.740,setiap bulan yang lebih besar daripada $10,39 \%$ standar keluarga miskin pada bulan Maret 2010, yaitu sebesar Rp. 211.726,-. Di samping itu menurut data dari Bank Dunia bahwa pada tahun 2001 menetapkan standar keluarga tidak mampu secara internasional lebih besar daripada penghasilan perkapita sebesar US\$ 275 setiap tahun atau sebesar 2 US\$ setiap hari (Emillia, 2018).

Demikian juga saat ini dimana Indonesia sedang giat melakukan pembangunan dalam skala besar dengan tujuan meningkatkan standar kehidupan penduduknya. Setiap kegiatan pembangunan selalu menimbulkan risiko. Risikonya berupa adanya perubahan yang mengakibatkan suatu aktivitas yang memiliki sifat alamiah, kimia, fisik serta biologi. Risiko yang memiliki nilai positif dapat berupa memberikan manfaat untuk kehidupan penduduk selanjutnya dan dapat juga memiliki sifat negatif berupa timbulnya hal-hal yang merugikan masyarakat itu sendiri.

Peningkatan jumlah penduduk tentu saja akan mengakibatkan semakin bertambahnya volume sampah terutama apabila tanpa disertai perbaikan sarana dan prasarana pengelolaan sampah. Tumpukan sampah dapat menyebabkan timbulnya bermacam-macam penyakit, perkotaan menjadi kumuh dan kotor, menimbulkan bau yang tidak sedap dan pencemaran lingkungan. Sehingga dengan demikian permasalahan sampah harus segera dicarikan jalan keluarnya untuk segera diatasi (Ni Komang Ayu Artiningsih, 2012). Dengan demikian sampah diperkotaan dihasilkan oleh penduduk yang bermukim diperkotaan dengan volume yang sangat besar, sehingga tidak dapat tertampung di tempat pembuangan akhir (TPA) (Surahma Asti Mulasari, 2014).

Berdasarkan data Kementerian Lingkungan Hidup pada tahun 2012 penduduk Indonesia berpotensi sebagai penghasil sampah sebesar 490.000 ton setiap hari atau sebesar 178.850.000 ton setiap tahun. Hal ini disebabkan karena kurangnya kesadaran masyarakat untuk menjaga kebersihan lingkungannya. Sebagian besar sampah tersebut merupakan sampah organik hingga mencapai jumlah sebesar $70 \%$ dari total sampah dan sebesar $28 \%$ merupakan sampah non organik sebagai objek kegiatan pengumpul sampah atau pemulung (Syafrizal, 2014). 
Sampah merupakan buangan yang tidak terpakai lagi. Besarnya volume sampah tersebut sesuai dengan pemakaian benda-benda yang digunakan penduduk sehari-hari. Oleh karena itu kegiatan olah sampah tersebut tergantung pada managemen pengelolaan kegiatan hidup masyarakat sehari-hari. Demikian juga dengan jenis sampah sangat tergantung dari jenis benda-benda yang dipakai. Sehingga pengelolaan sampah berkaitan dengan managemen gaya hidup penduduk dalam mengkonsumsi barang-barang sehari-hari.

Dalam hal ini diperlukan metode dan managemen untuk mengatasi volume sampah yang berlimpah karena sampah dapat menyebabkan pencemaran dan kerusakan lingkungan hidup. Managemen olah sampah yang menjadi kebiasaan penduduk hingga saat ini masih berupa pengumpulan sampah, pengangkutan sampah dan kemudian pembuangan sampah di tempat pembuangan akhir (TPA). Salah satu penyebabnya adalah terbatasnya area yang tersedia apabila akan membuka tempat pembuangan sampah baru, sehingga mengakibatkan tempat pembuangan akhir yang tersedia sekarang ini melebihi daya tampung produksi sampah.

Apabila ditinjau dari segi yuridis, maka berdasarkan Pasal 1 Ayat (3) UUD 1945 menentukan bahwa Indonesia merupakan negara hukum (rechstaat) dan bukanlah negara yang berdasarkan atas kekuasaan belaka (machstaat). Sehingga pemerintah dan aparat negara dalam melaksanakan kebijakannya selalu berdasarkan peraturan perundangan termasuk juga pengelolaan sampah (Direktorat Jenderal Cipta Karya, 2015),

Undang-Undang No. 18 Tahun 2008 Tentang Pengelolaan Sampah beserta Peraturan Pemerintah No. 81 Tahun 2012 menentukan bahwa paradigma konvensional yang selama ini dilakukan masyarakat dalam pengelolaan sampah berupa pengumpulan-pengangkutan-pembuangan harus dirubah dengan konsep pengelolaan sampah menjadi pengurangan dengan pradigma baru dengan cara mendaur ulang dan memanfaatkan kembali sampah atau yang dikenal dengan istilah reduce, reuse dan recycle.

Ketentuan tersebut di atas juga diperkuat dengan Peraturan Pemerintah No. 81 Tahun 2012 Tentang Pengelolaan Sampah Rumah Tangga yang difokuskan pada upaya pelestarian lingkungan melalui pengelolaan sampah sebagai sumber daya. Peraturan tersebut memungkinkan penetapan target pengurangan sampah dengan menekankan pentingnya pemilahan sampah di sumber asal serta mengimbau agar dilakukan daur ulang dan pemanfaatan kembali dalam desain produk dan kemasan (Direktorat Jenderal Energi Baru, Terbarukan Konsevasi Energi, 2015).

Hal yang disayangkan adalah pardigma reduce, reuse dan recycle memiliki hambatan berupa kurangnya kesadaran penduduk untuk melakukan pemilahan sampah. Oleh karena itu jalan keluar untuk mengatasinya melalui sosialisasi dan memberikan edukasi kepada penduduk untuk memilah sampah. Apabila dilihat lebih jauh sampah diindentifikasikan menurut jenis-jenisnya, yaitu :

1. Garbage atau sampah mengandung kadar air yang merupakan sisa pengolahan, sisa kegiatan memasak sehari-hari atau makanan yang membusuk, namun masih dapat digunakan sebagai bahan makanan organisme lainnya. Di samping itu dikenal juga rubbish atau sampah yang tidak mengandung air merupakan sisa pengolahan yang tidah membusuk dan dapat pula dibagi menjadi :

a. Sampah yang tidak mudah membusuk namun mudah terbakar.

b. Sampah yang tidak mudah membusuk dan tidak mudah terbakar.

2. Ashes dan cinder merupakan berbagai jenis abu dan arang yang berasal dari aktivitas pembakaran. 
3. Dead animal merupakan sampah yang berasal dari hewan yang sudah mati.

4. Street sweeping merupakan sampah yang berserakan di sepanjang jalan.

5. Industrial waste merupakan sampah yang berasal dari aktivitas industri yang jenisnya sama apabila dibandingkan jenis sampah lainnya.

(Arief Fadhilah, 2011)

Kemudian Direktur Jendral Cipta Karya mengklasifikasikan sampah menjadi sebagai berikut :

1. Sampah yang mengandung kadar air atau garbage merupakan sampah yang berasal dari sisa pengolahan, sisa makanan yang telah membusuk, namun dapat dijadikan makanan bagi organisme lainnya.

2. Sampah yang tidak mengandung kadar air atau rubbish merupakan sampah sisa pengolahan yang tidak mudah membusuk, namun mudah terbakar.

3. Sampah yang berbentuk halus merupakan jenis abu atau partikel-partikel kecil yang berterbangan yang akan mengganggu pernapasan dan mata.

4. Sampah yang berbahaya merupakan sampah patogen yang berasal dari rumah sakit atau klinik, sampah beracun sisa pestisida, kemasan pembungkus bahanbahan beracun, sampah radioaktif dan sampah yang mudah meledak.

5. Sampah berbentuk balokan atau bulky waste, yaitu mobil yang rusak dan tidak bisa dipakai lagi, kulkas yang sudah rusak, pohon yang tumbang dan batang kayu.

6. Sampah yang berada di jalan merupakan sampah yang bertebaran di sepanjang jalan seperti sisa kemasan dan sisa makanan, kertas dan dedaunan.

7. Sampah yang berasal dari binatang yang telah mati, seperti bangkai tikus dan ayam.

8. Sampah yang berasal dari bangunan, seperti : potongan kayu, pecahan genteng, batubata dan buangan adukan bangunan.

9. Sampah yang berasal industri yang berasal dari aktivitas industri.

10. Sampah khusus lainnya yang berasal dari benda-benda berharga atau sampah dokumentasi.

11. Sampah berasal dari kandang atau tempat pemotongan hewan yang berupa kotoran hewan, sisa makanannya, sisa daging, tulang dan isi perut serta bagian tubuh hewan lainnya.

12. Sampah yang berasal dari lumpur yang berbentuk dari lumpur selokan, saluran air, lumpur dari bangunan pengolahan, air buangan dan septic tank.

(Arief Fadhilah, 2011)

Menurut Direktur Jenderal Cipta Karya sampah memiliki ciri khas yang berbeda antara lain, yaitu :

1. Komposisi sampah yang dibagi menjadi dua klasifikasi, yaitu :

a. Komposisi fisik sampah yang mencakup besarnya prosentase dari komponen pembentuk sampah yang terdiri dari organik, kertas, kayu, logam, kaca dan plastik.

b. Komposisi kimia sampah terdiri dari unsur Karbon, Hidrogen, Oksigen, Nitrogen, Sulfur, Fosfor serta unsur lainnya yang terdapat di dalam protein, karbohidrat dan lemak. Komposisi kimia sampah erat kaitannya dengan pemilihan alternatif pengolahan dan pemanfaatan tanah.

2. Kepadatan sampah berdasarkan persatuan volume.

Direktoran Jenderal Cipta karya (1992) menyatakan bahwa kepadatan sampah diperlukan untuk menentukan ketebalan tumpukan sampah yang akan dibuang pada sistim sanitary landfill. Sedangkan apabila menggunakan sistim pengolahan maka informasi tersebut diperlukan untuk merencanakan dimensi unit proses. 
3. Kadar air sampah yang merupakan perbandingan antara berat air dengan berat sampah total atau berat kering sampah tersebut.

(Arief Fadhilah, 2011)

Selanjutnya sampah menimbulkan berbagai permasalahan sebagai berikut :

1. Aspek kesehatan

Sampah menjadi media yang sangat baik bagi berkembangnya berbagai jenis penyakit yang menyebabkan infeksi.

2. Aspek lingkungan hidup

Sampah mencemari lingkungan dan dapat menyebabkan banjir.

3. Aspek sosial ekonomi

Sampah dapat menghambat perkembangan pariwisata dan dampak yang lebih jauh lagi dapat menghalangi perkembangan otonomi daerah dan mengurangi minat para pemodal untuk menanamkan modalnya.

Apabila masalah persampahan tidak diselesaikan sebagaimana mestinya, maka akan menimbulkan berbagai permasalahan terutama dampak bagi kesehatan manusia serta makhluk lainnya. Pengelolaan persampahan yang baik merupakan suatu rangkaian kegiatan yang mencakup pengumpulan, pengangkutan, pengelolaan dan pembuangannya yang saling berkaitan (Rizal, 2011). Demikian juga pemilahan sampah sesuai jenisnya sebenarnya sudah berjalan dengan baik, namun kurangnya pengetahuan masyarakat akan pengolahan sampah ini tidak berjalan efektif sehingga banyak terjadi penumpukan sampah organik (Murni Yuniwasi, 2012).

Oleh karena itu sistim pengelolaan sampah di wilayah kota sekarang ini masih dilakukan dengan sistim sentralisasi dimana sampah dikelola langsung oleh pemerintah yang diawali dari penarikan retribusi sampah kepada penduduk, pengumpulan sampah dari penduduk dan kemudian diangkut serta dibuang ke tempat pembuangan akhir (TPA) oleh dinas kebersihan, contohnya pengolahan sampah di Jakarta. Dalam hal ini dapat dilihat peranan penduduk hanya bersifat pasif terhadap pengelolaan sampah yang diproduksinya. Sehingga diperlukan adanya edukasi pada penduduk dalam mengatasi pengelolaan sampah

Selanjutnya tulisan ini hanya membatasi situs penelitian hanya lingkup STTPLN saja karena berpotensi sebagai penghasil sampah yang cukup besar. STT-PLN yang memiliki aktivitas rutin bahkan di hari libur sudah tentu menghasilkan berbagai jenis sampah setiap harinya. Oleh sebab itu sudah sewajarnya apabila STT-PLN memiliki metode pengelolaan sampah yang baik dan mandiri. Berawal dari kenyataan tersebut di atas maka tulisan ini diharapkan dapat memberikan sumbangan pemikiran mengenai aplikasi fungsi managemen persampahan terpadu yang tepat bagi STT-PLN yang diharapkan dapat dikembangkan menjadi sistim percontohan pengelolaan sampah mandiri di berbagai wilayah rumah tinggal di perkotaan sehingga dengan demikian dapat membantu meringankan tugas pemerintah dalam pengelolaan sampah.

Dengan demikian dalam mendukung program pembangunan nasional harus dicari suatu metode pengelolaan sampah yang baik dan benar Selanjutnya maka yang menjadi pokok permasalahan dalam penelitian ini adalah bagaimana penerapan aplikasi fungsi managemen persampahan terpadu yang tepat bagi STT-PLN.

\section{METODOLOGI PENELITIAN}

Tulisan ini merupakan lanjutan dari penulisan sebelumnya yang berjudul : "Metode Yuridis Pengelolaan Sampah Rumah Tangga Dan Sampah Sejenis Di STTPLN", sehingga masih menggunakan metode penelitian dan analisa data yang sama seperti dalam penelitian sebelumnya dan observasi terhadap objek yang sama. 
Adapun situs penelitian ini dilakukan di tempat olah sampah (TOS) dan tempat pembuangan akhir (TPA) STT-PLN Jakarta (Emillia, 2018).

Dalam hal ini dilakukan penelitian bersifat eksplanatoris dengan melakukan obsevasi langsung dan mengamati kegiatan pengelolaan sampah di tempat olah sampah (TOS) dan tempat pembuangan akhir (TPA). Selanjutnya dilakukan wawancara dengan menggunakan teknik question and aswer dengan cara wawancara berstruktur (indepth interviewing). Wawancara yang dilakukan dengan penuh keakraban terhadap subjek yang diwawancarai. Jenis pertanyaan yang dilontarkan kepada subjek wawancara semakin rinci dan terfokus untuk mendapatkan informasi yang rinci dan mendalam. Melalui metode wawacara yang penuh keakraban ini membuat subjek wawancara memberikan informasinya secara jujur sehingga didapatlah informasi yang sebenarnya dan juga diharapkan dapat mengungkapkan kendala yang ada dalam proses olah sampah tersebut. Di samping itu juga dilakukan penelitian terhadap peraturan perundangan yang berlaku saat ini yang khusus mengatur tentang sampah (Emillia, 2018).

Adapun analisa terhadap data yang berhasil dikumpulkan tersebut berupa hasil observasi lapangan dan kepustakaan kemudian dilakukan analisa secara kualitatif sehingga dapat menjawab pokok permasalahan dalam penelitian ini yang kemudian disusun menjadi tulisan ilmiah yang merupakan hasil penelitian yang telah dilakukan. (Emillia, 2018).

\section{HASIL DAN PEMBAHASAN}

Berdasarkan hasil penelitian STT-PLN menghasilkan berbagai jenis sampah yang dapat dilihat dalam tabel berikut ini (Emillia, 2018):

Tabel 1. Jenis Sampah STT-PLN

\section{NO. PENGGOLONGAN JENIS SAMPAH SAMPAH}

1. Sampah yang tidak
mengandung air atau
kering

Plastik pembungkus berbagai kemasan makanan atau minuman, kotak kardus, tissu, kertas untuk membungkus kemasan makanan dan bermacammacam kertas untuk kegiatan kantor dan perkuliahan, alat-alat tulis yang tidak terpakai maupun yang tercecer, styrofoam untuk membungkus barang elektronik serta membungkus makanan.

2. Sampah yang
mengandung air atau
basah

Daun-daunan yang gugur, bekas potongan rumput, batang dan ranting pohon, berbagai macam sisa makanan dan minuman, yaitu sisa nasi dan sayur, tulang ikan, tulang ayam atau tulang sapi, sisa mie dan sisa gorengan serta berbagai sisa jajanan lainnya.

3. Sampah balokan Bekas meja dan kursi yang sudah rusak dan tidak dapat dipakai lagi atau bekas kawat logam dan tembaga atau berbagai macam logam/besi yang tidak dapat dipakai lagi.

Selanjutnya supaya lebih jelas akan disajikan gambar tempat pembuangan akhir (TPA) dan tempat olah sampah (TOS) di STT-PLN, yaitu : 


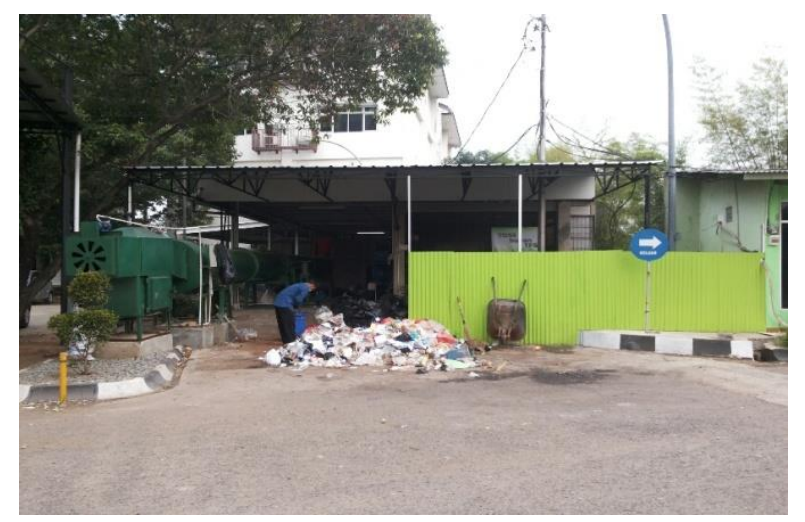

Gambar 1. Tempat Pembuangan Akhir (TPA) STT-PLN

Berdasarkan hasil penelitian berbagai jenis sampah yang terkumpul di tempat pembuangan akhir (TPA) dan tempat olah sampah (TOS) STT-PLN tersebut akan diperinci dalam tabel berikut ini :

Tabel 2. Volume Sampah STT-PLN

No.

Aktivitas

Volume Sampah

1. Hari kerja kegiatan Sebesar $1 \mathrm{~m}^{3}$ dalam kemasan kantong plastik perkantoran beserta kegiatan hitam yang berukuran $90 \mathrm{~cm} \times 120 \mathrm{~cm}$ kuliah. berjumlah sebanyak 20 kantong plastik.

2. Hari kerja kegiatan Sebesar $0,5 \mathrm{~m}^{3}$ dalam kemasan kantong plastik perkantoran tanpa kegiatan hitam yang berukuran $90 \mathrm{~cm} \times 120 \mathrm{~cm}$ perkuliahan. berjumlah sebanyak 10 kantong plastik.

3. Hari libur nasional dan akhir Sebesar $0,5 \mathrm{~m}^{3}$ dalam kemasan kantong plastik minggu/week end, namun terdapat kegiatan perkuliahan dan kegiatan kemahasiswaan non hitam yang berukuran $90 \mathrm{~cm} \times 120 \mathrm{~cm}$ sebanyak 10 kantong plastik.

perkuliahan yang bersifat tidak tetap dan diselenggarakan hanya pada waktu tertentu.

4. Hari libur nasional dan akhir Sebesar $0,1 \mathrm{~m}^{3}$ dalam kemasan kantong plastik minggu/week end, namun hitam yang berukuran $90 \mathrm{~cm} \times 120 \mathrm{~cm}$ sebanyak tidak terdapat perkuliahan 2 kantong palstik.

dan kegiatan kemahasiswaan apapun.

Dengan demikian berdasarkan tabel yang telah disajikan tersebut diatas, maka dapat disimpulkan bahwa STT-PLN berpotensi sebagai penghasil sampah yang besar. Berbagai jenis sampah yang terkumpul di tempat pembuangan akhir (TPA) dan tempat olah sampah (TOS) STT-PLN tersebut akan dipilih ke dalam dua golongan jenis sampah, yaitu :

1. Degradable waste atau biasa dikenal sebagai sampah organik.

Degradable waste atau biasa dikenal sebagai sampah organik adalah jenis sampah yang dengan mudah membusuk dan mengandung air yang tinggi dan dapat terurai kembali dengan mudah. Sehingga dapat dijadikan kompos yang berguna menyuburkan tanaman, misalnya berupa dedaunan, bekas potongan 
rumput dan rumput kering, dahan dan ranting pohon, sisa berbagai jenis makanan dan minuman, seperti sisa nasi dan sisa sayur, tulang ayam, tulang ikan dan tulang sapi, sisa mie, sisa gorengan atau sisa berbagai jenis jajanan maupun kegiatan masak-memasak makanan lainnya.

2. Undegradable waste atau biasa dikenal sebagai sampah anorganik adalah sampah yang sulit membusuk dan tidak dapat diuraikan kembali, namun dapat didaur ulang menjadi sesuatu yang bermanfaat. Degradable waste atau sampah organik terbagi atas dua jenis, yaitu :

a. Mudah terbakar, seperti kemasan pembungkus makanan dan minuman, kotak karton, tissu, kertas pembungkus makanan atau kertas yang dipergunakan untuk aktivitas perkantoran lainnya dan aktivitas perkuliahan dan bekas alatalat tulis yang rusak dan yang tercecer serta bekas meja dan kursi yang sudah rusak.

b. Sulit terbakar, seperti serpihan kaca, stryrofoam, bekas kawat logam dan berbagai jenis logam lainnya yang tidak terpakai.

(Emillia, 2018)

Berbagai jenis sampah tersebut di atas selanjutnya diolah menjadi kompos di tempat olah sampah (TOS) STT-PLN dengan menggunakan proses yang disebut dekomposisi atau fermentasi. Dalam hal ini sampah tersebut mengalami pelapukan sehingga memiliki warna yang berbeda dari sampah semula, tidak mengeluarkan bau, mengandung air yang sedikit pada suhu ruang atau kamar. Kegunaan kompos, yaitu sebagai :

a. Sumber asupan makanan bagi tanaman.

b. Melunakan tanah.

c. Meningkatkan struktur dan tekstur tanah.

d. Meningkatkan kesuburan tanah dan komposisi mikroorganisme di dalam tanah.

e. Mepererat kekuatan mengikat tanah dan air.

f. Memperlancar tumbuhnya akar tanaman baru.

g. Tempat penyimpanan air tanah dalam jangka waktu yang cukup lama.

h. Dapat digunakan di berbagai jenis lahan, seperti lahan pertanian, lahan perkebunan, reklamasi lahan kritis, maupun padang golf.

Kompos yang dihasilkan oleh tempat olah sampah (TOS) STT-PLN melalui cara fermentasi atau peuyemnisasi yang disimpan ke dalam keranjang bambu berukuran $1,3 \mathrm{~m}^{2}$ sebanyak $20 \mathrm{~cm}^{3}$ sampah yang kemudian dicampur dengan air lindi yang dihasilkan oleh Biodigester sampah organik. Gambar Biodisgester dapat dilihat berikut ini (Emillia, 2018):

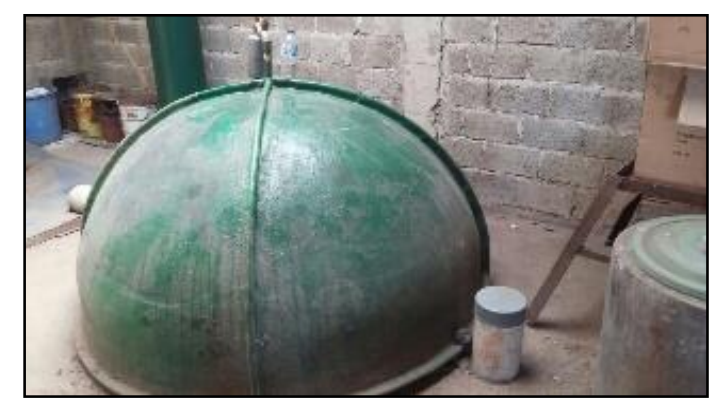

Gambar 2. Biodisgester

Tahap selanjutnya di dalam proses fermentasi atau peuyemnisasi tersebut sampah akan diinapkan dan disimpan selama sepuluh hari yang dapat dilihat dalam gambar di bawah ini (Emillia, 2018) : 


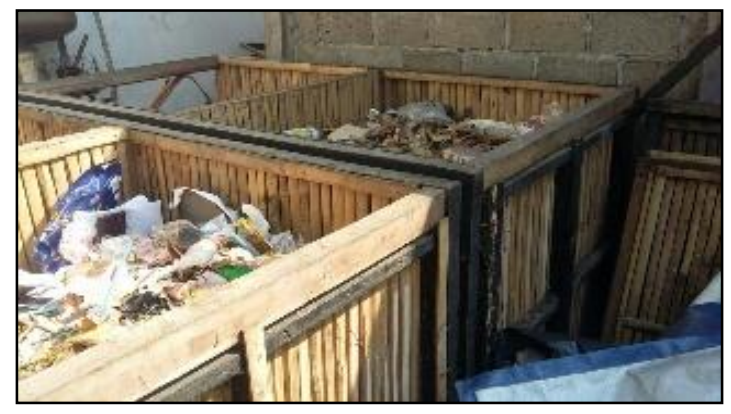

Gambar 3. Fermentasi Sampah

Setelah sepuluh hari diperam selanjutnya sampah tersebut akan dikeluarkan dari keranjang bambu kemudian akan dicincang dengan menggunakan Mesin Choper atau Klaser berikut ini (Emillia, 2018):

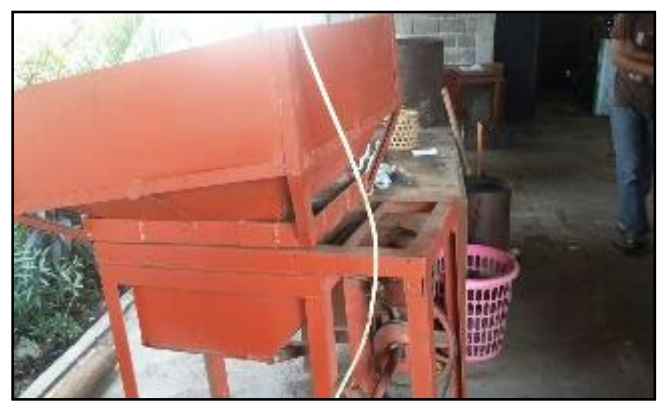

Gambar 4. Mesin Coper atau Klaser

Hasil penyincangan sampah tersebut berupa sampah kasar yang selanjutnya disaring menjadi sampah halus yang masih basah dengan menggunakan Mesin Saringan Putar yang dapat dilihat dalam tiga gambar berikut ini (Emillia, 2018) :

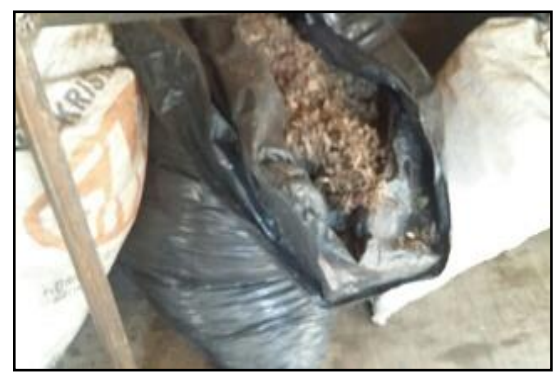

Gambar 5. Hasil Sampah Kasar

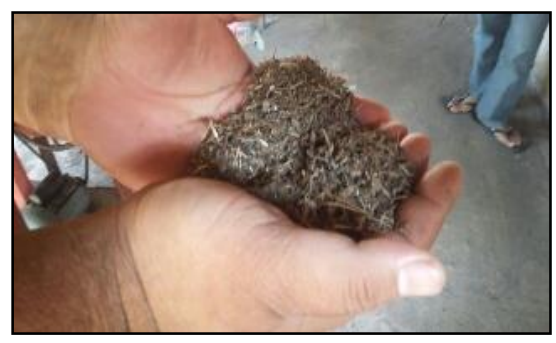

Gambar 6. Hasil Sampah Halus 


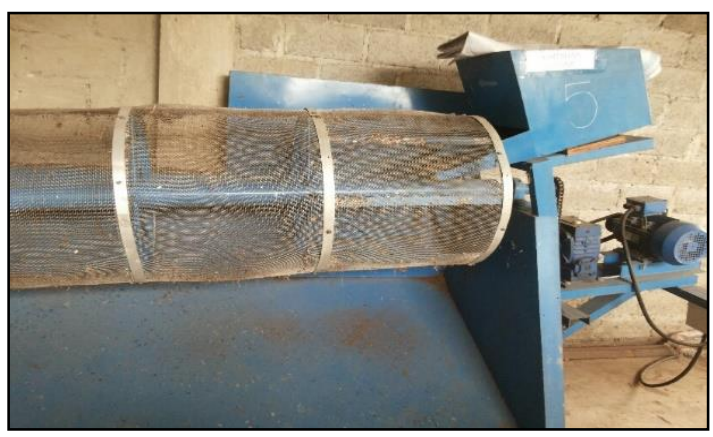

Gambar 7. Mesin Saringan Putar

Selanjutnya hasil akhir berupa sampah halus yang masih basah tersebut akan dikeringkan menggunakan Mesin Pengering Sampah dalam gambar di bawah ini :

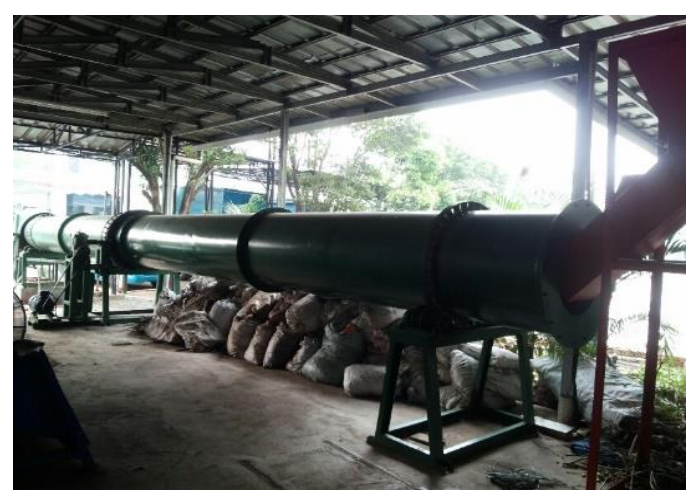

Gambar 8. Mesin Pengering Sampah

Setelah sampah halus yang masih basah tersebut dikeringkan selanjutnya akan dibuat menjadi briket seperti dalam gambar di bawah ini :

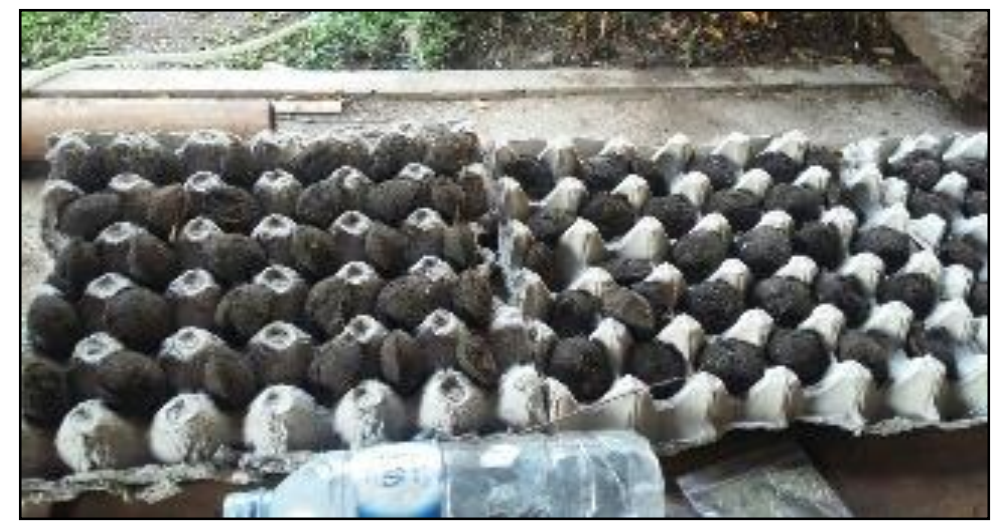

Gambar 9. Briket

Briket merupakan hasil produk daur ulang sampah yang dilakukan oleh tempat olah sampah (TOS) STT-PLN yang dapat digunakan sebagai bahan bakar pengganti fosil seperti bahan bakar minyak dan dapat diproduksi dalam jumlah besar dengan waktu produksi yang tidak memerlukan waktu yang lama karena metode yang digunakan relatif juga sangat sederhana. Sehingga dengan demikian juga dapat mengurangi pemakaian bahan bakar kayu yang bersumber dari hutan. Di samping itu penggunaan briket tersebut mengurangi biaya yang diperlukan untuk membeli bahan bakar minyak maupun gas. Keuntungan lainnya dapat memberikan penghasilan tambahan bagi penduduk apabila pembuatan briket yang berasal dari sampah tersebut dilakukan dengan cukup baik oleh penduduk. Dalam hal ini briket yang dihasilkan oleh tempat olah sampah (TOS) STT-PLN terdiri atas : 
1. Briket standar yang berasal dari proses daur ulang sampah organik/degradable waste yang dicampur dengan lem kanji yang berasal tepung sagu atau dikenal dengan kanji.

2. Briket yang berasal dari proses daur ulang sampah organik/degradable waste yang setelah difermentasi atau peuyemnisasi kemudian dicampur dengan lem kanji yang berasal dari tepung sagu atau dikenal dengan kanji dan dodol yang berasal dari lelehan plastik, karet atau logam setelah mengalami pemanasan, sehingga menghasilkan briket yang padat.

3. Briket yang berasal dari proses daur ulang sampah organik/degradable waste yang setelah difermentasi atau peuyemnisasi selanjutnya dicampur dengan arang halus dan lem kanji yang berasal dari tepung sagu atau dikenal dengan kanji, sehingga menghasilkan briket yang padat.

4. Briket yang berasal dari proses daur ulang sampah organik/degradable waste yang setelah difermentasi atau peuyemnisasi selanjutnya dicampur dengan kotoran manusia yang sudah dikeringkan dan lem kanji yang berasal dari tepung sagu atau biasa dikenal dengan kanji, sehingga menghasilkan briket padat.

(Emillia, 2018)

Oleh karena itu maka skema proses pengelolaan sampah di tempat olah sampah (TOS) STT-PLN digambarkan dengan alur yang dapat dilihat sebagai berikut, yaitu (Emillia, 2018) :

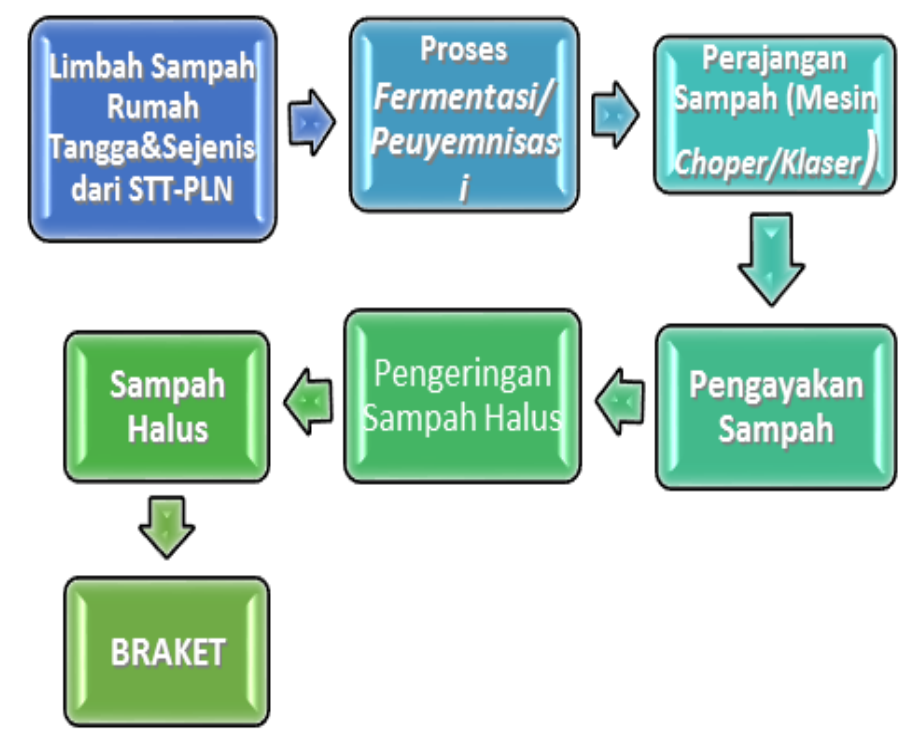

Gambar 10. Diagram Blok Alur Produksi Braket STT-PLN

Berdasarkan hasil penelitian yang dilakukan di tempat olah sampah (TOS) STTPLN tersebut di atas, maka selanjutnya akan dibahas secara rinci dengan menggunakan fungsi-fungsi umum dalam dasar-dasar managemen sebagai berikut:

1. Planning atau perencanaan

Kegiatan planning atau perencanaan dilakukan dengan menentukan tujuan dan strategi pengelolaan sampah, penetapan sarana dan prasarana serta penyusunan prosedur dalam pengelolaan sampah. Planning dalam pengelolaan sampah STTPLN dapat dilihat melalui:

a. Tujuan pelaksanaan pengelolaan sampah.

b. Sarana yang dibutuhkan dalam pengelolaan sampah.

c. Penyusunan prosedur dalam pengelolaan sampah.

(Jayanti Nigiana P.P., Endang Larasati, Nina Widowati).

2. Organizing atau pengorganisasian 
Kegiatan organizing dilakukan dengan menetapkan kegiatan yang diharuskan, menetapkan personil yang akan melaksanakannya dan pengelompokan tugas dan pihak yang harus bertanggung jawab terhadap tugas tersebut. Aktivitas-aktivitas yang dilakukan dalam organizing, yaitu :

a. Menetapkan sumber daya, baik manusia maupun keuangan dalam proses pengumpulan sampah.

b. Pengkoordinasian pengumpulan sampah STT-PLN.

c. Koordinasi antara pihak-pihak yang terkait dalam pengumpulan sampah.

d. Menentukan pihak yang bertanggung jawab dalam proses pengelolaan sampah di STT-PLN.

(Jayanti Nigiana P.P., Endang Larasati, Nina Widowati)

\section{Actuating}

Kegiatan actuating dilakukan dengan melaksanakan suatu proses kepemimpinan, pembimbingan dan memberikan motivasi kepada pekerja agar bekerja dengan efektif serta efisien dalam mencapai tujuan yang ditetapkan. Aktivitas actuating dalam pengelolaan sampah di STT-PLN meliputi :

a. Penugasan dalam program pengelolaan sampah di STT-PLN.

b. Pelatihan dan pengembangan yang diberikan dalam program pengelolaan sampah di STT-PLN.

(Jayanti Nigiana P.P., Endang Larasati, Nina Widowati).

4. Controlling atau mengendalikan

Kegiatan controlling dilakukan melalui penilaian kinerja pengelolaan sampah berdasarkan standar yang sudah ditetapkan, perbaikan apabila dibutuhkan serta melakukan pemantauan, evaluasi dan pemberian alternatif solusi penyelesaiannya. Controlling dalam managemen pengelolaan sampah di STTPLN yaitu :

a. Pemantauan dalam pengelolaan sampah.

b. Mengevaluasi kembali keberhasilan proses mencapai tujuan dan target.

c. Memberikan alternatif penyelesaian masalah yang terjadi dalam mencapai tujuan yang ditetapkan.

(Jayanti Nigiana P.P., Endang Larasati, Nina Widowati)

Selanjutnya hasil penelitian yang telah dilakukan tersebut menunjukan bahwa managemen pengelolaan sampah di STT-PLN sudah dilakukan dengan baik karena telah menggunakan fungsi-fungsi managemen dalam pengelolaan sampah, yaitu :

1. Planning atau perencanaan

a. Alasan Pengelolaan sampah.

Berdasarkan hasil wawancara yang dilakukan di tempat olah sampah (TOS) STT-PLN menunjukan bahwa pelaksanaan kegiatan pengelolaan sampah adalah untuk memenuhi ketentuan yang diatur dalam Undang-Undang No. 18 Tahun 2008 Tentang Pengelolaan Sampah. Semua ketentuan yang mengatur mengenai prosedur dan tujuan pengelolaan sampah telah diatur di dalam undang-undang tersebut. Hasil wawancara menunjukan bahwa alasan pelaksanaan kegiatan pengelolaan sampah dikarenakan semakin bertambahnya jumlah mahasiswa dalam proses kegiatan mengajar sehari-hari seiring dengan perkembangan waktu dan kemajuan teknologi. Penanganan masalah sampah masih banyak menghadapi permasalahan berupa kebiasaan masyarakat yang membuang sampah dengan paradigma lama, yaitu mengumpulkan-mengangkut ke tempat pembuangan sampah tanpa melakukan pemilahan serta kurangnya kemauan masyarakat untuk melakukan pengolahan sampah yang dihasilkannya sehingga mengakibatkan timbunan sampah 
semakin besar. Kurangnya kesadaran masyarakat mengenai pentingnya menjaga kelestarian lingkungan menyebabkan kurangnya kepedulian terhadap lingkungan sekitarnya karena pada dasarnya kewajiban pengelolaan lingkungan tersebut, bukan saja menjadi tanggung jawab pemerintah saja tetapi juga tanggung jawab masyarakat bersama-sama.

b. Sarana dan prasarana pendukung.

Sarana dan prasarana dalam pengelolaan sampah yang dimiliki oleh tempat olah sampah (TOS) STT-PLN berupa: lahan/tempat yang digunakan untuk kegiatan pengelolaan sampah dan juga peralatan, seperti Biodisgester, bak bambu fermentasi sampah, Mesin Choper atau Klaser, Mesin Saringan Putar dan Mesin Pengering Sampah. Tempat dilaksanakannya kegiatan pengelolaan sampah ini berada di lingkungan kompleks STT-PLN, sedangkan peralatanperalatan diperoleh berdasarkan dana yang bersumber dari dana swadaya dari STT-PLN sendiri.

c. Prosedur

Prosedur dan mekanisme pengelolaan sampah di STT-PLN sudah dilaksanakan berdasarkan Undang-Undang Nomor 18 Tahun 2008 Tentang Pengelolaan Sampah. Pelaksanaan pengelolaan sampah STT-PLN terdiri atas pengurangan dan penanganan sampah. Pengurangan sampah yang diatur dalam Pasal 20 Ayat (1) ketentuan tersebut meliputi kegiatan-kegiatan berikut :

a. Melakukan pembatasan atau bahkan menghindari terjadinya sampah yang bertumpuk.

Dalam hal ini sampah yang tertampung setiap hari di tempat pembuangan akhir (TPA) STT-PLN tersebut dalam waktu yang relatif tidak lama harus segera diolah di tempat olah sampah (TOS) STT-PLN.

b. Melakukan proses daur ulang atau recycle sampah yang terkumpul tersebut menjadi briket sebagaimana yang telah dijelaskan dalam uraian di atas.

Peraturan perundangan yang berkaitan dengan pelaksanaan pengelolaan sampah diatur secara rinci dalam Undang-Undang No. 18 Tahun 2008 Tentang Pengelolaan Sampah sudah cukup dapat memberikan jalan keluar dalam mengatasi masalah persampahan. Walaupun kebiasaan yang terjadi di tengah masyarakat sekarang ini masih menggunakan paradigma konvensional yang berkonsep mengumpulkan-mengangkut-membuang atau disebut end of pipe, maka diharapkan untuk selanjutnya terjadi perubahan paradigma masyarakat menjadi lebih modern dengan menggunakan konsep 3P atau 3R yang ditentukan dalam ketentuan tersebut berupa : reduction (mengurangi)-reuse (menggunakan kembali)-recycling (mendaur ulang) sebagaimana dapat dilihat melalui dua gambar di bawah ini : 


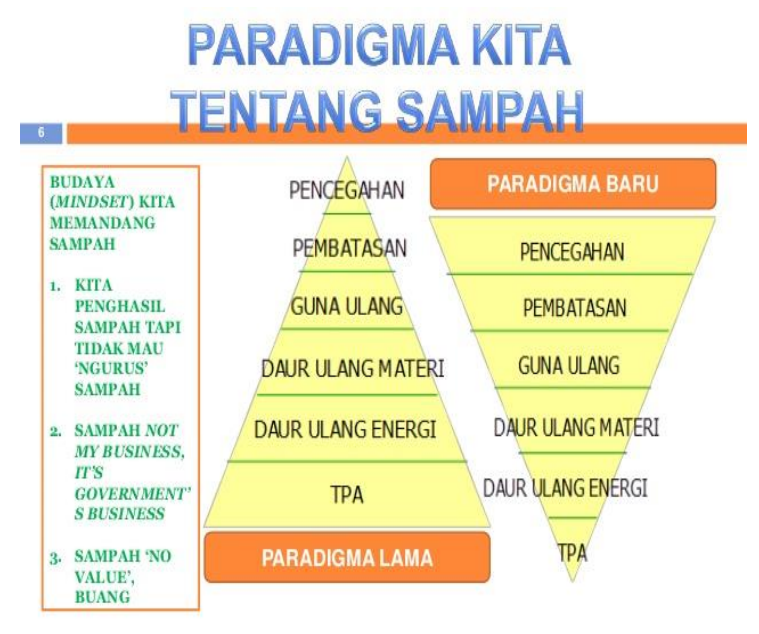

Emillia, (2018)

Gambar 11. Paradigma Pengelolaan Sampah

Apabila diperhatikan dalam gambar yang disajikan di atas terlihat jelas paradigma perbedaan pengelolaan sampah. Paradigma lama tidak akan memberikan pemecahan permasalahan dibidang sampah. Malahan jumlah sampah akan menumpuk dan meningkat dan menimbulkan biaya yang besar serta belum lagi menimbulkan dampak negatif pencemaran terhadap lingkungan. Sedangkan metode baru sampah akan diproses dan diolah menjadi produk akhir seperti briket yang dihasilkan oleh STT-PLN dengan demikian dapat dilihat dalam gambar berikut ini, yaitu :

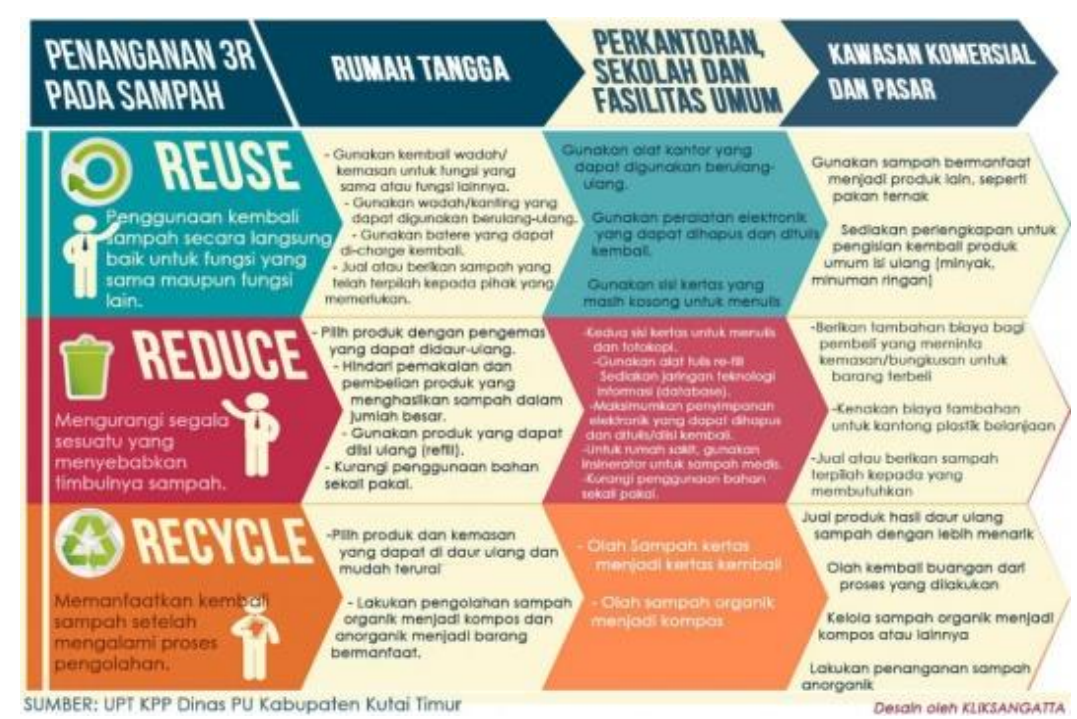

Gambar 12. Pengelolaan Sampah Secara 3R

Dengan demikian seperti yang terjadi di tengah masyarakat sampai dengan saat ini yang masih menggunakan managemen olah sampah yang menggunakan paradigma lama dengan konsep konvensional berupa mengganggap sampah merupakan barang yang tidak berguna sehingga harus dibuang, selanjutnya sekarang menggunakan paradigma baru dimana sampah masih dapat dipergunakan kembali dengan cara pendaur ulangan yang diolah kembali sehingga menghasilkan barang baru yang berguna dan dapat memberikan tambahan penghasilan pada masyarakat. 
2. Organizing atau pengelolaan

a. Pihak-pihak yang berperan.

Program pelaksanaan sampah terpadu yang dilaksanakan di STT-PLN Jakarta dilaksanakan secara swadaya oleh petugas dari STT-PLN yang mewakili masyarakat dan pemerintah Kecamatan Duri Kosambi yang memiliki peran penting dalam pengelolaan sampah secara umum di Kecamatan Duri Kosambi yang sesuai dengan Pasal 5 Undang-Undang No. 18 Tahun 2008 Tentang Pengelolaan yang berbunyi sebagai berikut: "Pemerintah dan pemerintahan daerah bertugas menjamin terselenggaranya pengelolaan sampah yang baik dan berwawasan lingkungan sesuai dengan tujuan sebagaimana dimaksud dalam Undang-Undang ini."

b. Koordinasi dalam pengelolaan sampah.

Kegiatan koordinasi secara formal hanya dilakukan sekali dalam setahun oleh Kecamatan Duri Kosambi, Cengkareng Jakarta Barat karena keterbatasan dana anggaran yang diterima.

\section{Actuating}

a. Pembagian tugas.

Dalam pengelolaan sampah di STT-PLN, dibentuk tim pengelolaan sampah yang para anggotanya adalah petugas dari STT-PLN yang dianggap mampu melaksanakan tugas dan sesuai dengan pengalaman yang telah dimiliki. Selanjutnya Kecamatan Duri Kosambi berperan sebagai Pembina, sedangkan petugas STT-PLN sebagai pelaksana kegiatan.

b. Pelatihan ketrampilan dan penyuluhan.

Dalam rangka meningkatkan pengetahuan dan ketrampilan masyarakat dalam pengelolaan sampah, pihak kecamatan memberikan program pelatihan dan penyuluhan bagi masyarakat sebagai bekal untuk terjun dalam kegiatan pengelolaan sampah di Duri Kosambi.

4. Controlling atau pengendalian

Kegiatan pengawasan dilakukan oleh pihak Kecamatan Duri Kosambi yang dilaksanakan sekali dalam setahun karena anggaran dana yang tidak mencukupi. Sehingga masyarakat yang memiliki permasalahan tidak dapat berkonsultasi dan memberikan pendapatnya dalam pengelolaan sampah dan mengakibatkan turunnya minat masyarakat untuk mengikuti kegiatan pengelolaan sampah tersebut.

5. Kendala yang dihadapi.

Berdasarkan hasil penelitian yang dilakukan, maka dapat diketahui bahwa permasalahan dalam kegiatan pengelolaan sampah di STT-PLN yaitu sebagai berikut :

a. Kurangnya kesadaran peserta didik dalam membuang sampah ke tempat sampah yang disediakan di berbagai tempat yang telah disediakan oleh STTPLN. Dalam hal ini masih banyak ditemukan sampah-sampah yang berceceran di mana-mana, seperti di dalam kelas, di koridor maupun berbagai tempat di lingkungan STT-PLN baik yang berupa sampah yang dihasilkan dari aktivitas mengajar seperti kertas sebagai media menulis dan mencatat dan alat-alat tulis baik tertinggal maupun sengaja ditinggal begitu saja, berbagai tugas mahasiswa dan maket yang sengaja ditinggal begitu saja maupun sisa pembungkus kemasan makanan dan minuman atau pembungkus kemasan lainnya yang jumlahnya cukup banyak.

b. Walaupun telah disediakan tempat sampah di berbagai tempat di lingkungan STT-PLN, namun hal yang disayangkan adalah tempat sampah yang 
disediakan tersebut belum dipisahkan menjadi tempat sampah organik dan tempat sampah non organik. Sehingga sampah yang terkumpul di tempat sampah bercampur menjadi satu antara sampah organik dan sampah non organik. Di samping itu peserta didik dan pegawai STT-PLN masih menganggap bahwa pembuangan sampah ke tempat sampah sesuai dengan jenis sampahnya bukanlah kewajiban mereka. Walaupun di beberapa lokasi yang merupakan fasilitas umum, misalnya di stasiun kereta api, mall, hotel dan gedung perkantoran lainnya sudah disediakan tempat sampah yang terpisah, baik tempat sampah organik untuk menampung sampah organik maupun tempat sampah non organik untuk menampung sampah non organik.

c. Kurangnya pengetahuan di kalangan peserta didik dan pegawai STT-PLN mengenai apa yang dimaksud degan sampah organik ataupun non organik.

d. Kurangnya pemberian edukasi dan pengarahan di STT-PLN mengenai pentingnya membuang sampah yang benar apalagi menggunakan paradigma baru dengan konsep reduction (mengurangi)-reuse (menggunakan kembali)-recycling (mendaur ulang) seperti yang ditentukan dalam peraturan perundangan.

e. Walaupun STT-PLN telah memiliki tempat pembuangan akhir (TPA) dan tempat olah sampah (TOS) yang mandiri dalam arti dikelola dan dilaksanakan secara mandiri oleh STT-PLN, namun produk hasil daur ulang atau olah sampah yang menghasilkan briket, tetap saja menemui kendala dalam memasarkan briket tersebut dikarenakan rendahnya minat masyarakat untuk membeli briket yang dapat digunakan sebagai pengganti bahan bakar fosil berupa minyak dan gas.

\section{KESIMPULAN}

Setelah dijelaskan secara mendalam dalam tulisan di atas, maka yang menjadi kesimpulan yaitu :

1. Pengelolaan sampah yang dilakukan di tempat olah sampah (TOS) STT-PLN sudah menggunakan paradigma yang berkonsep reduction (mengurangi)-reuse (menggunakan kembali)-recycling (mendaur ulang) dengan pelaksanaan sebagai berikut :

a. Melakukan pemilahan sampah dengan cara menyediakan dua jenis tempat sampah untuk menampung sampah organik dan non organik, namun sayangnya dua jenis tempat sampah terpisah ini hanya tersedia di bagian lobby utama yang berdekatan dengan empat buah lift. Sedangkan di bagian gedung lainnya dari lantai 2 sampai dengan lantai 12 belum disediakan dua jenis tempat sampah terpisah dan juga di tempat lainnya termasuk masjid dan dua gedung tambahan dan halaman STT-PLN.

b. Melakukan pembuatan kompos.

c. Melakukan recycling atau mendaur ulang sampah menjadi briket.

2. Kegiatan pengelolaan sampah sudah menggunakan fungsi dasar managemen yang baik dengan cara planning atau perencanaan, organizing atau pengelolaan, controlling atau pengawasan dan actuating.

3. Hasil penelitian menunjukan bahwa masih terdapat kekurangan dalam kesadaran peserta didik maupun pegawai STT-PLN untuk melakukan pengelolaan sampah dengan paradigma berkonsep reduction (mengurangi)-reuse menggunakan kembali)-recycling (mendaur ulang). 


\section{SARAN}

Selanjutnya maka yang menjadi saran penulis dalam tulisan ini yaitu :

1. Melakukan kegiatan edukasi dan pelatihan kepada peserta didik dan pegawai STT-PLN serta masyarakat mengenai pengelolaan sampah secara terus menerus. Sehingga paradigma pengelolaan sampah dengan konsep 3R berupa reduce, reuse dan recycle dapat diterapkan dalam kehidupan sehari-hari.

2. Meningkatkan kesadaran peserta didik dan pegawai STT-PLN termasuk juga masyarakat agar lebih bijaksana dalam menghadapi permasalahan sampah dengan memberikan pelatihan dan sosialisasi dalam pengelolaan sampah dengan menggunakan paradigma yang berkonsep 3R tersebut.

3. Menjalin hubungan kerjasama kemitraan dengan berbagai lembaga yang kegiatannya memiliki fokus dan scoop dalam melakukan pengelolaan sampah dengan mengajukan permohonan proposal CSR yang ditujukan ke berbagai lembaga perbankan maupun yayasan lainnya agar dapat membantu menyediakan dana yang diperlukan.

4. Mengikutsertakan hasil olahan produk sampah berupa briket ke acara-acara pameran yang diselenggarakan oleh pemerintah maupun lembaga swasta lainnya dengan cara menitipkan atau menyewa boot.

5. Meningkatkan kwalitas hasil olahan produk sampah berupa briket tersebut menjadi kualitas unggulan, sehingga dapat menarik minat dan daya beli masyarakat.

\section{DAFTAR PUSTAKA}

Arief Fadhilah, H. S. (2011). Kajian Pengelolaan Sampah Kampus Jurusan Arsitektur Fakultas Teknik Universitas Diponegoro. Modul Vol 11, No. 2, 62-71.

Direktorat Jenderal Cipta Karya. (2015). Panduan Penyusunan Rancangan Peraturan Daerah Pengelolaan Sampah. Jakarta: Kementrian Pekerjaan Umum dan Perumahan Rakyat.

Direktorat Jenderal Energi Baru, Terbarukan Konsevasi Energi. (2015). Sampah Menjadi Energi. Jakarta: Kementrian Energi dan Sumber Daya Mineral Republik Indonesia.

Emillia. (2018). Metode Yuridis Pengelolaan Sampah Rumah Tangga Dan Sampah Sejenis Di STT-PLN. Kilat Jurnal Kajian Ilmu dan Teknologi, 7-14.

Jayanti Nigiana P.P., Endang Larasati, Nina Widowati. (t.thn.). Manajemen Pengelolaan Sampah Di Kecamatan Tembalang. Semarang: Jurusan Administrasi Publik Fakultas Ilmu Sosial Dan Ilmu Politik Universitas Diponegoro.

Murni Yuniwasi, F. I. (2012). Optimasi Kondisi Proses Pembuatan Kompos Dari Sampah Organik Dengan Cara Fermentasi Menggunakan EM4. Jurnal Teknologi, Vol. 5 No. 2, 172-181.

Ni Komang Ayu Artiningsih, S. P. (2012). Peran Serta Masyarakat Dalam Pengelolaan Sampah Rumah Tangga (Studi Kasus Di Sampangan\&Jombang, Kota Semarang. Jurnal Serat Acitya, Jurnal Ilmiah UNTAG Semarang, Vol. 1, No. 2, 107-114.

Rizal, M. (2011). Analisis Pengelolaan Sampah Perkotaan (Studi Kasus Pada Kelurahan Boya Kecamatan Banawa Kabupaten Donggala. SMARTek Vol. 9 No. 2, 155-172. 